\title{
Linking brand attitude to word-of-mouth and revisit intentions in the restaurant sector
}

\section{Linking brand attitude to word-of-mouth}

Pantea Foroudi

Middlesex University, London, UK

Maria Palazzo

University of Salerno, Fisciano, Italy, and

Asfia Sultana

Middlesex University, London, UK
Received 15 November 2020 Revised 9 April 2021 23 May 2021 Accepted 8 June 2021

\begin{abstract}
Purpose - Following the planned behaviour theory, the aim of the paper is to analyse the role played by brand attachment, brand characteristics and congruence in enhancing brand attitude while leading to revisit intentions and word-of-mouth (WOM) in the restaurant sector.

Design/methodology/approach - The study is based on the quantitative method and considered 464 questionnaires fulfilled by customers of restaurants. The data were explored employing the partial least square-structural equation modelling (PLS-SEM).

Findings - This study expands the literature about WOM and revisit intentions. The paper states that brand attitude positively influenced revisit intentions and WOM. Besides, findings highlighted that analysed concepts were positively correlated and that they played an important role in impacting revisit intentions and WOM, apart from one factor: social self-congruity, which was not significantly related to brand attitude.

Practical implications - The results of this paper show practitioners how to develop suitable strategies that set the bases for developing customer loyalty and repeat business. By putting into practice these suggestions in the restaurant sector, brands can easily build up their attitude and boost a positive WOM and the intention to revisit.

Originality/value - The study offers a conceptual framework to explore the significance of several factors, including revisit intentions and WOM. In practice, taking into account the proposed framework, it is suggested that restaurant managers should assess these two items using several factors including congruence, brand characteristics and brand attachment.
\end{abstract}

Keywords Brand attachment, Word-of-mouth (WOM), Congruence, Revisit intention, Brand characteristics, Brand attitude

Paper type Research paper

\section{Introduction}

Several researchers have shown that building a strong brand is the main goal of any company (Liu et al., 2012; Zha et al., 2020). Many organisations, including restaurants (Kim and Ok, 2009; Namin, 2017), while building their brand, take into consideration the phenomenon of customers' brand repurchase intention or revisiting intention (Mizik, 2014). This is usually done by analysing consumers' attitude towards the brand (Hwang and Ok, 2013). The attitude of the consumer towards the brand is defined as the perspective that the consumer has in his/her mind about the brand (Chatzopoulou and Tsogas, 2017; Liu et al., 2017, 2020).

(C) Pantea Foroudi, Maria Palazzo and Asfia Sultana. Published by Emerald Publishing Limited. This article is published under the Creative Commons Attribution (CC BY 4.0) licence. Anyone may reproduce, distribute, translate and create derivative works of this article (for both commercial and noncommercial purposes), subject to full attribution to the original publication and authors. The full terms of this licence may be seen at http://creativecommons.org/licences/by/4.0/legalcode

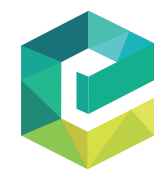

British Food Journal Vol. 123 No. 13, 2021 pp. $221-240$ Emerald Publishing Limited 0007-070X 
BFJ

123,13

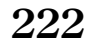

Furthermore, consumers' brand attitude is influenced by different items, such as brand characteristics, brand attachment and congruence (Aaker, 1996). The bond between consumer and brands expresses the emotional proximity that consumers feel towards the brand (BahriAmmari et al., 2016). Besides, brand attitude is affected by brand features, too (Keller, 2008). The brand characteristics are attributes that link the brand and its clients (Bowden, 2009). However, congruence expresses the brand reliability (O'Cass and Weerawardena, 2010). These topics are analysed in different business industries, and they show their strength in the restaurant sector, too (Bahri-Ammari et al., 2016; Aureliano-Silva et al., 2019).

In addition, it is useful to highlight that boosting brand awareness and developing a positive brand perception are strategies that can be attained by leveraging brand attitude (Zhang et al., 2018). In order to succeed in effectively managing a brand, there is the need to offer consumers in-depth information about the brand and to create significant brand attributes that can help customers to make the decision of visiting again (Zhang et al., 2018). Past research about the intention to revisit and brand attitude among customers, in general, and among clients of restaurants, in particular, has highlighted that these concepts can offer benefits in terms of brand loyalty (Lee et al., 2009; Hussein, 2018). The main advantage that brand loyalty gives to consumers is to ensure them about the level of quality that the brand is able to offer: it can impact consumers when they make the decision to revisit and/or repurchase the specific brand (Fouladivanda et al., 2013; Liu and Lee, 2016).

In competitive markets, especially in hospitality, different barriers are set by companies that reach a high level of brand loyalty (Nam et al., 2011; Jin et al., 2012). These organizations are able to attain higher sales level and income; decrease costs for attracting customer; prevent consumers' vulnerability to competitors' tactics; reach a higher rate of customer retention; focus on lower flexibility of price; enhance margin of profit; sustain premium price strategies, etc. (Brexendorf et al., 2010; Chatzopoulou and Tsogas, 2017).

On the other hand, consumers can have an adverse reaction against brands when they develop a negative attitude towards a certain brand or a company (Han et al., 2019). These circumstances play a significant role in influencing consumers' buying decision (Zhang et al., 2018) due to the fact that consumers consider brands as a way to shed light on quality, characteristics, personality, etc. (Kim and Joung, 2016).

In order to create consumers brand engagement, it is important to leverage a positive attitude and strong brand loyalty. However, it must be highlighted that not employing these items in the right way can damage the brand and boost negative word-of-mouth (WOM) (Wetzer et al., 2007; Pace et al., 2017). The WOM is highly spread in places/locations where companies and consumers "meet" each other, such as, for example, shops and, in this case, restaurants (Zhang et al., 2014; Ansary and Hashim, 2018). As employees are the source of engagement for customers (Fu et al., 2017), they are able, in these places, on one side, to enhance their clients' experience, but, on the other side, they can create negative experiences and offer a negative facet of the brand (Brexendorf et al., 2010). Therefore, the interaction between brands and consumers can help brand attitude to affect both WOM and revisit intentions (Lee et al., 2018; Rajput and Gahfoor, 2020).

Several authors have shown the existence of a link among brand awareness, brand association, brand reputation, brand attitude and purchase intention (Bhatta, 2016; Ahn and Back, 2018). This relationship has been explored in the restaurant sector, too (Han et al., 2015; Lu et al., 2015; Rajput and Gahfoor, 2020). The studies stated that brand prominence can positively affect purchase intentions (Butcher et al., 2016; Han et al., 2016). Han et al. (2019), in particular, explored the positive relationship between brand image, brand reputation and purchase intention. In addition, Razak et al. (2019) highlight that there is a positive impact of brand awareness on the repurchase intention and WOM, while brand attitude exerts a moderating effect. It has also been shown that brand attitude can positively affect purchase intentions (Ghorban, 2012). On the same line, brand attitude can be related to WOM, with the 
mediating effect of satisfaction and loyalty (Casidy and Wymer, 2015). Besides, in the restaurant sector, other research analysed the mediation of WOM on brand attachment, brand image, brand attitude, brand awareness and brand equity (Assiouras et al., 2015; Hanaysha, 2016; Jalilvand et al., 2016).

Starting from this discussion, it has been recognized that there is still little evidence on cause-effect relationship among brand attachment (self-connection and prominence), brand characteristics (brand awareness, brand image, perceived quality, brand loyalty and brand prominence), congruence (ideal self-congruity, actual self-congruity, social self-congruity and ideal social self-congruity), WOM and revisit intentions, with the mediating role played by brand attitude in the restaurant sector. As noted by Aaker (1996), Razak et al. (2019), who conducted similar studies in the past, the necessity and urgency of understanding the relationships of those variables is high, as previous works do not incorporate all variables selected in the current paper. Besides, in practice, there is the need for restaurant managers to assess the selected items not only individually but also to try to find the main impacts and effects that link them all in order to have clearer insights on how to reach positive WOM and increase revisit intentions.

Therefore, following the insights of the theory of planned behaviour (TPB), the aim of the research is to explore the role played by brand attachment, brand characteristics and congruence in developing brand attitude while leading to revisit intentions and WOM in the restaurants of Karachi (Pakistan). Thus, the paper aims at answering the questions: (1) What is the impact of brand attachment, brand features and congruence on brand attitude? (2) What is the impact of brand attitude on WOM and on revisit intentions? (3) What is the impact of WOM on revisit intentions?

\section{Conceptual framework and hypotheses development}

The paper investigates the selected topics following the insights of the TPB. The perspective was set by Ajzen (1985) and shows that personal behaviour is the consequence of behavioural intentions, which is influenced by three items: personal attitude toward a specific behaviour, personal values and perceived behavioural control (Ajzen, 1985, 2002). In fact, in this perspective, attitude is linked to personal feelings regarding several behaviours (George, 2004).

This research selected the TBP, as it helped the authors to structure two assumptions on the basis of the paper. First of all, this study differentiated perceived controlling behaviour from attitude. As highlighted by Ajzen (2002), personal controlling behaviour does not involve behaviour that will result in a specified outcome, but it indicates a personal step of controlling the performance of behaviour. Thus, the perceived controlling behaviour expresses the perception of the restaurant brand equity. Secondly, this work analysed real behaviour instead of behavioural intentions as dependent variables. This choice is in line with Ajzen (2002) consideration, as the author stated that intentions are encouragement variables that impact behaviour. This entails that the higher is the intention of performing behaviour, the higher is the chance that an individual can perform the specific behaviour. In this research, the behaviour is influenced by the strong brand attitude towards a particular restaurant. Previously, the positive relationship between intention and behaviour was studied by Godin and Kok (1996) and Heath and Gifford (2002). Hence, the study takes into account the actual behaviour, i.e. WOM and revisit intentions, and considers them as dependent variables (Ajzen, 2002).

Furthermore, since this study focuses on the restaurant industry, several theories linked with branding in the service sector were taken into account. Starting from the analysis of this field of research developed by Camp (1996) and Saunders and Watters (1993), this paper highlights that, as it happens with the branding of products, services branding is centred on finding the right target market and, afterwards, creating a strong offer and a brand 
$\mathrm{BFJ}$ 123,13

\section{4}

personality that can be easily identified, preferred and selected by customers. In addition, this research is in line with previous studies that suggest that there is a difference in terms of perceived risk and related customer engagement, both within certain kinds of products and within different services. In fact, Parasuraman (1987) said that there are two main features of service transactions. The first one entails the final result, while the second one deals with the way in which the service is offered. Building a brand strategy in the service sector, thus, involves setting a relationship not only between the marketer and the customer but also the employees in charge of delivering the service's promises, and the customer has to be considered (Dall'Olmo Riley and De Chernatony, 2000). Each encounter, actually, examines the company's capability to keep its promises during the so-called "the moment of truth". As such, the members of the staff in charge of delivering a service are seen by customers as part of it (Grace and O'Cass, 2005) and are able to personify the main characteristic of the brand, especially in this specific sector (Sarker et al., 2019). Therefore, the employees have to share the values and philosophy of the organisation if they are in charge of communicating and delivering the brand promise (Parasuraman, 1987). This is even truer when there is the need to analyse the service provided in the restaurant, as in this case (Robinson et al., 2005; Erkmen and Hancer, 2019).

The following sections offer a discussion regarding the nexuses between the selected concepts and presents the research hypotheses that are summarised in a conceptual model (see Figure 1).

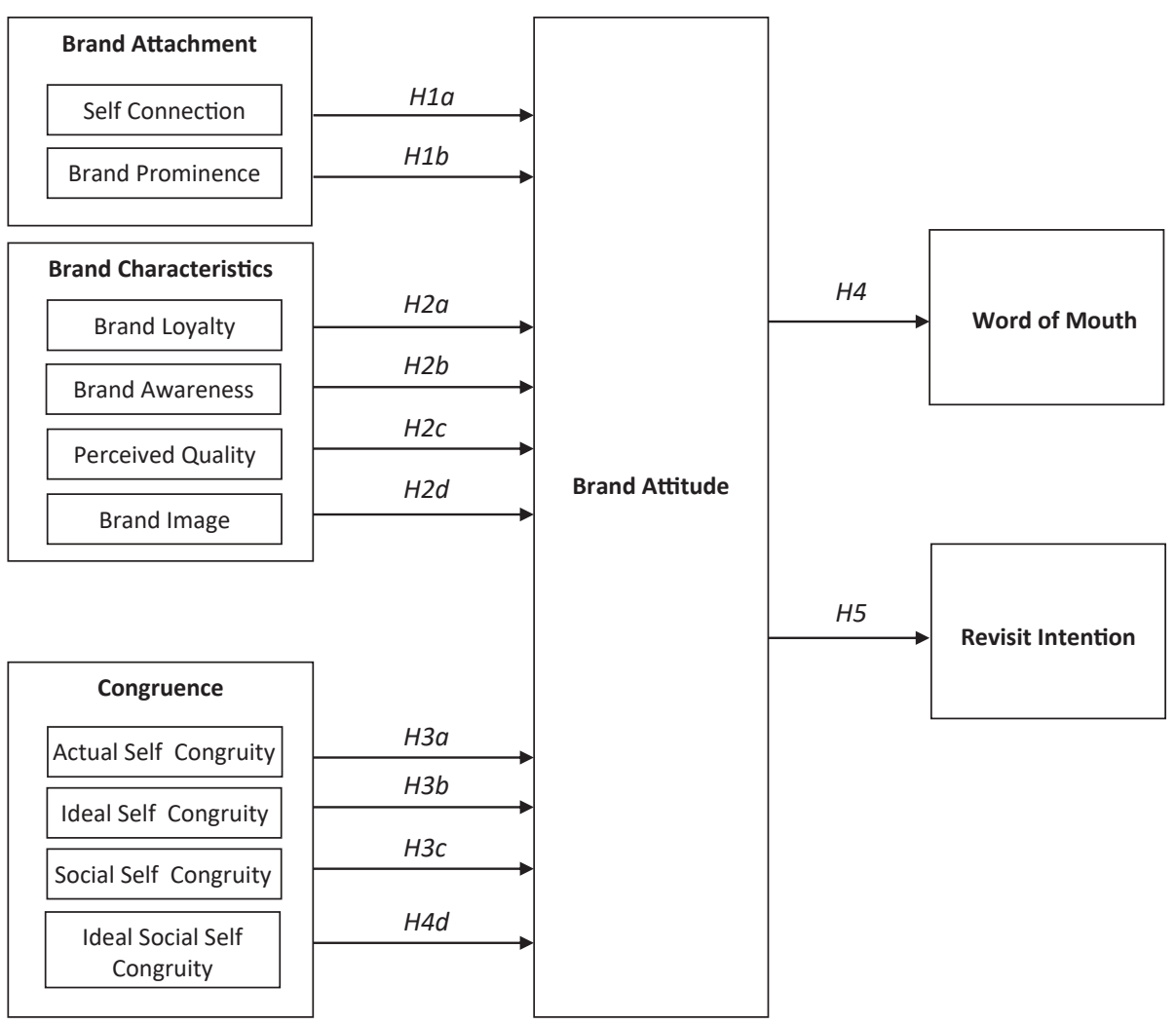

Figure 1.

The conceptual model

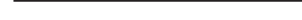


Brand attachment (self-connection and brand prominence) and brand attitude

Several past studies have analysed the existing connection between brand attachment and brand attitude in several fields including the restaurant industry. For example, BahriAmmari et al. (2016) examined the relationships between satisfaction, congruence, nostalgic connections and trust, referring to brand attachment and behavioural loyalty. Behavioural loyalty was explored through the consumer's intention to maintain the relationship with luxury restaurants. Moreover, Chen et al. (2017) developed a model to evaluate the effects of excessive packaging of goods on the attachment of green brand and investigate the impacts of green brand image and brand attitude.

In this field, it is clear that customers decide to interact every day with many brands, but only with few of these brands create a self-connection. Chatzopoulou and Tsogas (2017) investigated the impacts of buying attachments and brand attitudes in the retail scenario. The analysis identified the effects of emotions in consumption and provided retailers with an instrument to understand the psychological side of their customers. In the restaurant sector, Kim and Stepchenkova (2018) focussed on examining the consumer experiential value in Korean restaurants and highlighted its impact on consumption emotions, self-connective brand attachment and brand loyalty. This study shows that experiential value influences positively or negatively emotions, and emotions linked with self-connective brand attachment mediate the relationships between the perceived value of the restaurant and brand loyalty.

In this field, social media marketing has reached huge importance, and managers are trying to find guidance in order to target the right publics who will interact with their brands. VanMeter et al. (2018) investigated this issue, leveraging on the attachment theory. In fact, they examined the attitude and attachment toward social media and brands while exploring the possibility that a consumer can act as a brand advocate. Thus, this work offered some guidance for reaching customers who are more willing to advocate for brands through social media.

In addition, Singh and Banerjee (2018) considered four Indian brands that communicated thanks to celebrity endorsement. The authors highlighted the fact that advertisement and brand attitude expressed in terms of self-connection and brand prominence impacted customer purchase intention. The study has shown the credibility of celebrities while impacting brand attachment; it also had positive effects on the attitude of consumers related to advertisements and brands.

Thus, the study proposes that:

H1a. The more favourable the brand attachment in terms of self-connection is, the more favourable the brand attitude will be.

H1b. The more favourable the brand attachment in term of brand prominence is, the more favourable the brand attitude will be.

\section{Brand attitude and brand characteristics (perceived quality, brand awareness, brand image and brand loyalty)}

Focussing on the role played by brand attitude and brand characteristics in the restaurant sector, Jalilvand et al. (2016) proposed a model that incorporates antecedents and consequences of brand preference. This research highlighted that brand personality and brand equity can be considered antecedents of brand preference, while brand preference is positively related to WOM. On the same line, Liu et al. (2017) explored the impact of consumer-based brand equity (CBBE) and its factors (loyalty, perceived quality, awareness and brand trust) on consumer attitude and the intention to buy. Findings highlighted that CBBE factors positively affect brand attitude and the intention to buy, while brand
Linking brand attitude to word-of-mouth 
$\mathrm{BFJ}$

123,13

awareness significantly impacts the intention to buy only through the mediation of brand attitude.

Exploring the growing importance of social networking sites (SNSs), Langaro et al. (2018) introduced a framework that evaluated the impact of consumer engagement in SNSs on brand awareness and brand attitude. The study analysed brand-like Facebook pages. The results highlighted that consumer engagement directly affects brand awareness. This involves that there is a link between brand attitude and consumer engagement, while brand awareness mediates this relationship.

Ogunnaike et al. (2017) offer a framework that aid in understanding the relationship between $\mathrm{CBBE}$ and buying behaviour. Four different dimensions were used to express equity. This study included the Aaker brand equity model to understand the correlation between constructs. Results suggested that brand loyalty, seen as an issue linked with brand equity, affects the buying intention. Besides, brand awareness positively affected consumer buying behaviour, while brand attitude was considered as significantly able to boost buying behaviour.

Seo et al. (2015) examined the role of different marketing strategies and their relationship with brand loyalty. Besides, the moderating role of a brand image was examined. Findings showed that there was a positive - but negligible - impact between the considered concepts and that the moderation of brand image on physical environment and brand loyalty was nonsignificant.

Bauman and Taylor (2019) analyzed items that affect the consumer intention to be in touch with the brand and to continue this relationship. Results showed that brand loyalty and attitude were related to the intention of customers to continue to prefer the brand. However, consumer perception about service quality was non-significantly related to consumer intention.

Lee et al. (2018) explored the complementary product fit, the brand awareness and their effect on brand attitude. They showed that brand awareness significantly impacted brand attitude. Additionally, this research offered a deeper understanding of brand awareness in relationship to brand equity.

Thus, all these considerations based on previous studies propose that

H2. The more favourable (a) brand loyalty, (b) brand awareness, (c) perceived quality and (d) perceived quality are, the more favourable brand attitude will be.

\section{Congruence (social self-congruity, ideal self-congruity, actual self-congruity, ideal social self- congruity) and brand attitude}

Referring to the relationships between congruence (actual self-congruity, ideal self-congruity, social self-congruity and ideal social self-congruity) and brand attitude, Wassler et al. (2019) propose that self-congruity, seen as the relationship between perceived self-identity and perceived brand identity, is an antecedent of brand attitude. Furthermore, Pradhan et al. (2016) proposed a model in order to compare the effectiveness of user-brand personality similarity on brand purchase and brand attitude. Findings showed that brand personality similarity impacts buying intention and brand attitude, while congruence does not seem to have any effect on these items.

In order to study self-congruity (SC), Gonzalez-Jimenez et al. (2019) explored the supply chain effects' validity and identified the moderating effect of cultural variables. This study showed that there is a hold of actual SC, while ideal SC is held on consumers with independent self-construal only. On the other hand, Rezza (2018) investigated how self-image congruence impacts the brand attitude of different products. This research seems to be in line with other studies that suggested that self-congruence impacts and boosts positive attitude and behaviour towards several products. In fact, the findings revealed that self-congruence of consumers can predict the brand attitude of users. 
In addition, Kumagai and Nagasawa (2019) highlighted that there is an existing link between the prestige of store location, brand attitude, brand luxury and SC of the location. The findings showed that the prestige of location negatively impacted actual SC and that it positively affects ideal social SC. Moreover, actual SC positively affected brand attitudes for non-luxury brands and non-significantly impacted luxury brand attitude. Finally, ideal social SC positively impacted luxury brand attitude and non-significantly impacted non-luxury brand attitude. Similar results were reached in the restaurant sector by Han et al. (2016). Thus, all these considerations based on previous studies propose that

H3. The more favourable the (a) actual self-congruity, (b) ideal self-congruity, (c) social self-congruity, (d) ideal social self-congruity are, the more favourable brand attitude will be.

\section{Brand attitude and revisit intention}

Analysing the existing link between brand attitude and revisit intentions, Han et al. (2009) examined the relationships between customer satisfaction, consumption emotions, switching barriers and revisit intentions in the restaurant sector. Their results highlighted that consumption emotions significantly impacted customer satisfaction, and satisfaction mediated the impact of emotions on the revisit intention.

Moreover, Ahn and Back (2018) stated that a good reputation enhanced brand attitude. Besides, leveraging brand values helped to attain the behavioural brand intention. Furthermore, the mediating role of experience and attitude considerably impacted the relationship between reputation and the behavioural intention of revisiting the brand. In the service sector, Han et al. (2019) explored the process of revisit and repurchase intentions. The authors considered as antecedents of the process several factors such as quality, coreproduct, image perception, attitude and level of trust. In particular, all items selected in this study showed a strong relationship with the revisit and repurchase intention.

Furthermore, Park and Lee (2019) examined the behavioural intention of tourists in revisiting the destination. The analysis offered some insights about the fact that offering a quiet environment impacted tourist brand attitude, which finally led to enhancing their intention to visit. Thus, these considerations based on previous studies propose that

H4. The more favourable brand ttitude is, the more favourable the revisit intention will be.

\section{Brand attitude and WOM}

Analysing the existing link between brand attitude and WOM, several studies developed in different business sector can be considered. In the restaurant sector, Jalilvand et al. (2016) explored brand preference and its relationships with brand equity, brand personality and WOM. In the same business area, Zhang et al. (2021) showed that brand authenticity impacts WOM through perceived value and brand identification. Additionally, this analysed link is positively moderated by cultural involvement.

Ansary and Hashim (2018) addressed the relationship between consumer-based brand equity and image. The moderating effect of product features and WOM was explored on the current relationship. Findings suggested that brand image positively affected factors of brand equity (brand attachment, brand awareness and brand attitude). Furthermore, Pace et al. (2017) analysed how social media and mass media publics respond to the brand crisis, focussing on brand attitude and WOM. The study highlighted that the public exposed through social media to brand crisis show a more negative response to the brand than those exposed through traditional media. Besides, Herold et al. (2016) explored WOM in relation to the attitude of consumers. The results stated that WOM coming from family members 
$\mathrm{BFJ}$

123,13

228

boosted consumer brand attitude due to the fact that customer trusted more the source than the message itself.

In addition, Rafiee et al. (2016) explored the effect of different corporate strategies on brand attitude, focusing on the analysis of the moderating impact that the forum category and consumer motivations for expressing negative opinions can have on the existing link between corporate response approaches and brand attitude. The research studied the factors that can help companies successfully respond to negative e-WOM. Findings showed that conflict management strategies can aid managers to boost consumer revisit intentions and brand loyalty. Thus, all these considerations based on previous studies propose that:

H5. The more favourable brand attitude is, the more favourable WOM will be.

\section{Method \\ Setting}

Currently, the hospitality and restaurant sectors have had a huge expansion around the world, especially in emerging markets (Sikandar and Ahmed, 2019). An emerging market where these sectors are highly expanded is Pakistan. Pakistan is becoming a geographical area where tourists prefer to go in order to visit cultural locations (Malik et al., 2013) and to taste traditional food (Khan and Shaikh, 2011). Pakistani food is well-known due to its flavour and features linked with the characteristics of the five provinces present in the country (Punjab, Baluchistan, Sind, Khyber Pakhton-khuwa and Gilgit Baltistan) (Saeed et al., 2013). This has led to the fact that different local and international food chains have increased their presence in urban areas all over the country (Sabir et al., 2014). Thus, there is the need to explore the sector in Pakistan, as new trends in this field can offer a wide range of opportunities to restaurant managers.

\section{Sampling design and data collection}

The sample population of this paper involves clients of restaurants in Karachi (Pakistan). To measure the study's model, a pilot study was conducted between $50 \mathrm{PhD}$ respondents in order to examine the suitability, freedom from error, and validity of the research items via exploratory factor analysis (EFA) (De Vaus, 2002). Afterward, the data was collected from the sample population according to the N10 formula (Hair et al., 2014). Following the N10 formula where $N=14$, meaning $14(10)=140$, the authors decided that a minimum of 140 responses are needed in order to reach the generalizability of the results. Thus, 520 questionnaires were distributed to the sample population: 466 responses were collected, while 2 responses were incorrectly filled. Therein, the valid questionnaires were 464 responses, reaching a response rate of $92.8 \%$. However, due to some missing data, 16 data were removed, and the analysis focussed on 448 valid responses. In particular, among collected responses, 53.64\% were answered by males between 25 and 30 years old (57.1\%), who were holding a master degree (\%78.6) with income above 40.000 PKR (approximately 220 Euros) $(42.9 \%)$ (Table 1$)$.

The data was collected based on the non-probability convenience sampling technique. This technique involves that scholars collect the data selecting the population that is accessible to them considering its proximity to the researcher and the profile of the sample (Daniels et al., 2014). Moreover, the research implied the non-probability convenience sampling, as it allowed collecting considerable amounts of data without limitations such as money restraint, time constraint, etc.

\section{Measures}

Previous item measurements have been used in this study. Brand awareness, image and loyalty were measured via Liu et al. (2017) study. To measure brand attitude and WOM, the 


\begin{tabular}{|c|c|c|c|c|}
\hline & & Frequency & $\%$ & Linking brand \\
\hline \multirow[t]{2}{*}{ Gender } & Male & 240 & 53.6 & word-of-mouth \\
\hline & Female & 208 & 46.4 & \\
\hline \multirow{4}{*}{ Age group } & $<25$ & 112 & 25.0 & \\
\hline & Between 25 and 30 & 256 & 57.1 & \\
\hline & Between 31 and 36 & 48 & 10.7 & \\
\hline & Above 36 & 32 & 7.1 & 229 \\
\hline \multirow[t]{3}{*}{ Education } & Bachelors & 64 & 14.3 & \\
\hline & Masters & 352 & 78.6 & \\
\hline & Others & 32 & 7.1 & \\
\hline \multirow[t]{5}{*}{ Monthly Income } & Currently not working & 48 & 10.7 & \\
\hline & 10,000-19,999 PKR $(50-100 €)$ & 96 & 21.4 & \\
\hline & $20,000-29,999$ PKR $(100-150 €)$ & 16 & 3.6 & \\
\hline & $30,000-39,999$ PKR $(150-200 €)$ & 96 & 21.4 & Demographic \\
\hline & Above 40,000 PKR (Above $200 €$ ) & 192 & 42.9 & profile $(n=448)$ \\
\hline
\end{tabular}

validated items from Ansary and Hashim (2018) were employed. The measurement of the actual self-congruity (Kumar, 2016), Brand Prominence (Butcher et al., 2016), ideal self-congruity (Fastosoa and González-Jiméneza, 2018) were based on previous studies, too. In addition, ideal social self-congruity (Anand and Kaur, 2017), perceived quality (Liu et al., 2017), revisit intentions (Wu and Wang, 2014), self-connection (Kwon and Mattila, 2015) and social self-congruity (Han and Hyun, 2012) were also obtained from existing scales (WebAppendix-1). All items were measured using a seven-point Likert scale $(1=$ strongly disagree, 7 = strongly agree).

\section{Analysis and model testing}

PLS-SEM was used to assess the proposed model, and the analysis includes separate examinations of the measurement model and structural model. The measurement model was employed to assess the validity and reliability of the construct measures.

This study examined the internal consistency reliability via composite reliability and Cronbach's $\alpha$. The results show that the items have CR above $0.80 \alpha$, which are acceptable (Nunally and Bernstein, 1994). As the Web Appendixes 2 and 3 illustrates, the discriminant validity and convergent validity (AVE) were tested for each construct, following Fornell and Larcker (1981) criterion and Heterotrait-Monotrait (HTMT) ratio. The results were above 0.50, demonstrating that they are average and that there are no discriminant validity issues. Therefore, the structural model estimation was employed to investigate hypotheses.

\section{Structural model assessment}

Following the construct measures, the structural model results were assessed. Firstly, the collinearity between constructs before estimation of the path coefficient was examined. By testing the structural model for collinearity, the results show that each predictor has a VIF value lower than five. Then, the significance of path coefficients helped to explore the associations offered by the model.

Results in Table 2 showed that self-connection $(0.423, p<0.05)$, brand prominence $(0.145$, $p<0.05)$, brand loyalty $(0.267, p<0.05)$, brand awareness $(0.202, p<0.05)$, perceived quality $(0.323, p<0.05)$, brand image $(0.165, p<0.05)$, actual self-congruity $(0.196, p<0.05)$, ideal selfcongruity $(0.189, p<0.05)$ and ideal social self-congruity $(0.354, p<0.05)$ have a significantly positive effect on brand attitude at $95 \%$ confidence interval. Results showed that increasing 


\begin{tabular}{llccc}
\cline { 3 - 4 } BFJ & & Estimate & Prob & Decision \\
\cline { 2 - 5 } & Self-connection $\rightarrow$ brand attitude & 0.423 & 0.000 & Accepted \\
& Brand prominence $\rightarrow$ brand attitude & 0.145 & 0.002 & Accepted \\
& Brand loyalty $\rightarrow$ brand attitude & 0.267 & 0.000 & Accepted \\
& Brand awareness $\rightarrow$ brand attitude & 0.202 & 0.000 & Accepted \\
$\mathbf{2 3 0}$ & Perceived quality $\rightarrow$ brand attitude & 0.323 & 0.000 & Accepted \\
& Brand image $\rightarrow$ brand attitude & 0.165 & 0.000 & Accepted \\
& Actual self-congruity $\rightarrow$ brand attitude & 0.196 & 0.000 & Accepted \\
Table 2. & Ideal self-congruity $\rightarrow$ brand attitude & 0.189 & 0.005 & Accepted \\
Direct effect analysis & Social self-congruity $\rightarrow$ brand attitude & 0.004 & 0.931 & Rejected \\
using PLS-SEM & Ideal social self-congruity $\rightarrow$ brand attitude & 0.354 & 0.000 & Accepted \\
& Brand attitude $\rightarrow$ revisit intention & 0.812 & 0.000 & Accepted \\
& Brand attitude $\rightarrow$ WOM & 0.565 & 0.000 & Accepted \\
\hline
\end{tabular}

the components and determinants of brand attachment, brand characteristics, and congruence can lead to improve brand attitude of restaurants. However, social selfcongruity $(0.004, p>0.05)$ has no statistically significant effect on brand attitude, highlighting that this facet of congruence does not have any implications for restaurants' brand attitude.

Based on result of Table 3 , results show that brand attitude significantly mediates the relationship of self-connection $(0.239, p<0.05)$, brand prominence $(0.082, p<0.05)$, brand loyalty $(0.151, p<0.05)$, brand awareness $(0.114, p<0.05)$, perceived quality $(0.182, p<0.05)$, brand image (0.093, $p<0.05)$, actual self-congruity $(0.111, p<0.05)$, ideal self-congruity $(0.107, p<0.05)$ and ideal social self-congruity $(0.200, p<0.05)$ on WOM. In line with Zhao et al. (2010), the above-mentioned effect of brand attitude was complementary mediating. Nevertheless, brand attitude does not mediate the relationship between social self-congruity $(0.002, p>0.05)$ and WOM, as brand attitude has no-effect non-mediation nature (Zhao et al., 2010).

Table 3.

Specific indirect effect analysis using PLS-SEM

\begin{tabular}{lccc}
\hline Mediator: Brand attitude & Estimate & Prob & Decision \\
\hline Self-connection $\rightarrow$ WOM & 0.239 & 0.000 & Accepted \\
Brand prominence $\rightarrow$ WOM & 0.082 & 0.003 & Accepted \\
Brand loyalty $\rightarrow$ WOM & 0.151 & 0.000 & Accepted \\
Brand awareness $\rightarrow$ WOM & 0.114 & 0.000 & Accepted \\
Perceived quality $\rightarrow$ WOM & 0.182 & 0.000 & Accepted \\
Brand image $\rightarrow$ WOM & 0.093 & 0.000 & Accepted \\
Actual self-congruity $\rightarrow$ WOM & 0.111 & 0.000 & Accepted \\
Ideal self-congruity $\rightarrow$ WOM & 0.107 & 0.006 & Accepted \\
Social self-congruity $\rightarrow$ WOM & 0.002 & 0.931 & Rejected \\
Ideal-social self-congruity $\rightarrow$ WOM & 0.200 & 0.000 & Accepted \\
Self-connection $\rightarrow$ revisit intention & 0.344 & 0.000 & Accepted \\
Brand prominence $\rightarrow$ revisit intention & 0.118 & 0.002 & Accepted \\
Brand loyalty $\rightarrow$ revisit intention & 0.217 & 0.000 & Accepted \\
Brand awareness $\rightarrow$ revisit intention & 0.164 & 0.000 & Accepted \\
Perceived quality $\rightarrow$ revisit intention & 0.262 & 0.000 & Accepted \\
Brand image $\rightarrow$ revisit intention & 0.134 & 0.000 & Accepted \\
Actual self-congruity $\rightarrow$ revisit intention & 0.159 & 0.000 & Accepted \\
Ideal self-congruity $\rightarrow$ revisit intention & 0.154 & 0.005 & Accepted \\
social self-congruity $\rightarrow$ revisit intention & 0.003 & 0.931 & Rejected \\
Ideal social self-congruity $\rightarrow$ revisit intention & 0.288 & 0.000 & Accepted
\end{tabular}


Table 3 highlighted that brand attitude exerts a complementary mediation between selfconnection $(0.344, p<0.05)$, brand prominence $(0.118, p<0.05)$, brand loyalty $(0.217, p<0.05)$, brand awareness $(0.164, p<0.05)$, perceived quality $(0.262, p<0.05)$, brand image $(0.134$, $p<0.05)$, actual self-congruity $(0.159, p<0.05)$, ideal self-congruity $(0.154, p<0.05)$ and ideal social self-congruity $(0.288, p<0.05)$, while brand attitude has no-effect and non-mediation nature (Zhao et al., 2010) between social self-congruity $(0.003, p>0.05)$ and revisit intentions.

In addition, Table 4 provides the result of predictive relevance of the endogenous latent constructs of the structural model framework based on the Geisser (1975) cross-validating technique using PLS blindfolding at six omissions (Hair et al., 2016). Table 4 highlighted that brand attitude can be explained by its respective exogenous latent constructs up to $79.7 \%$ with the predictive relevance of $69.1 \%$. Equally, a revisit intention can be explained up to $66 \%$ with a relevance of $44.1 \%$, and WOM can be predicted up to $31.9 \%$ with the relevance of $17.4 \%$. Exploring predictive relevance of endogenous constructs, Hair et al. (2016) stated that $Q^{2}$ needs be higher than 0, while Hair et al. (2014) said that $R^{2}$ of 0.75 is considered as substantial. 0.50 considered as moderate and 0.25 or below are weak. In the same way, $Q^{2}<0.02$ is considered to have a weak predictive relevance, $0.02<Q^{2}<0.15$ is considered to have a moderate relevance, and $Q^{2}>0.35$ is considered to have a strong or substantial predictive relevance (Hair et al., 2016).

\section{Discussions}

The findings offer insight into the relationship between brand attachment, characteristics, congruence, attitude, WOM and revisit intentions in the restaurant sector. With reference to H1a, the paper showed that self-connection positively impacted brand attitude, which was previously analysed by Moore and Homer (2008). This can be explained by the fact that clients of the restaurant who feel they are connected with the brand can show a strong brand attitude. The results seem to be also in line with Ferraro $\mathrm{et} \mathrm{al}$. (2013), who suggested a positive relationship between self-connection and brand attitude, as customers feel to have a connection with brands when they think to have the right perception about brands: this can imply the chance to create a positive brand attitude.

About H1b, results show that brand prominence positively impacted brand attitude. This is in line with previous research (Jalilvand et al., 2016) that showed that brand prominence, considered as "the extent to which the appearance of the brand possesses characteristics designed to make it the central focus of audience attention," (Gupta and Lord, 1998, p. 48) can significantly affect brand attitude.

Besides considering H2a, brand loyalty positively influenced brand attitude, which resonates with previous studies (Gómez-Suárez et al., 2016; Liu et al., 2020). This existing relationship is due to the fact that when clients of restaurants who are loyal to the brand decide to eat in a specific location, they also boost their brand attitude, especially when they feel that the service they received is in line with their expectations.

Other studies focused on the analysis of the main features of the restaurant sector that have ascertained the existence of a positive relationship between brand awareness and brand attitude, as they were highlighted in this research in the H2b (Liu et al., 2020). This result can involve that the more the client understands the service he/she receives in restaurants, the

\begin{tabular}{lccc}
\hline Endogenous constructs & $R$ square & $R$ square Adjusted & $Q$ square \\
\hline Brand attitude & 0.797 & 0.792 & 0.691 \\
A revisit intention & 0.660 & 0.659 & 0.441 \\
WOM & 0.319 & 0.317 & 0.174
\end{tabular}

\section{Linking brand attitude to word-of-mouth}

231 
BFJ

123,13

more numerous are opportunities to positively learn about it and to create a positive effect on the brand attitude of the client.

With reference to $\mathrm{H} 2 \mathrm{c}$, the results seem to be in line with other studies in the selected business area (Sean Hyun and Kim, 2011), which highlights that perceived brand quality can positively impact brand attitude. This can be due to the fact that if perceived brand quality reflects the client expectation - while assessing the main features of the service offered by a restaurant - it can result in enhancing a positive brand attitude.

Moreover, considering H2d, it has been highlighted in this research, as stated by other past analyses in the restaurant sector (Sean Hyun and Kim, 2011; Erkmen and Hancer, 2019; Liu et al., 2020), that brand image and brand attitude are positively linked to each other. This entails that good experiences with the brand of a certain restaurant can boost its brand image and positively affect the brand attitude. This also resonates with Faircloth et al. (2001), which indicated that the better the brand image is in the minds of the customer, the more the chances of achieving a good brand attitude can be set.

Besides, the achieved results about H3a are in line with Kim (2015), who stated that actual self-congruity positively influenced brand attitude. The positive relationship between actual self-congruity and brand attitude has been partially studied before in the restaurant sector by (Kang et al. (2012). It highlights that the higher the actual self-congruity of clients of a restaurant is, the more they seem to be connected to the brand of this specific restaurant, and the better the brand attitude is.

Additionally, considering H3b, our findings seem to be consistent with previous research (Kumagai and Nagasawa, 2019) that show the existence of a positive relationship between ideal self-congruity and brand attitude. This achieved result is interesting as it highlights that clients ideally see themselves linked with the restaurant brand, and it succeeded in positively impacting the brand attitude towards the restaurant, too.

With reference to H3c, our study seems not to reflect any previous studies developed on the selected topics. In fact, according to Kumagai and Nagasawa (2016), social self-congruity was positively associated with brand attitude, while in our study, the result is the opposite. This means that clients' perception of how they are socially associated with the brand image of a restaurant - i.e. social self-congruity - seems not to be in line with how they want to be perceived in terms of brand attitude.

Moreover, the achieved findings of H3d are in line with Sirgy (2018). In fact, the collected data show that there is a positive relationship between ideal social self-congruity and brand attitude. This relationship enriches the previous understanding of the role played by the chosen concepts in the restaurant industry, as it sheds light on the fact that clients' ideal social perception of association with the brand positively impacts brand attitude.

In addition, with reference to $\mathrm{H} 4$, the paper states that the brand attitude positively influenced WOM. This was previously showed by Podnar and Javernik (2012), who said that the stronger the attitude towards the brand is, the more positive the WOM about the brand will be. Furthermore, this result also resonates with Martin (2017) and Zhang et al. (2021), who identified that if customers had a good brand attitude, it resulted in spreading a positive WOM about the brand.

Finally, confirming H5, brand attitude positively affected the revisit intention, as previously highlighted by Sinthamrong and Rompho (2015). This result enhanced our understanding of the brand attitude and revisit intentions in the restaurant sector, as it showed that the brand attitude is crucial for reinforcing the brand revisit intention.

\section{Theoretical and managerial implications}

Due to the rising competitiveness of restaurants in the current scenario, scholars and practitioners need to find strategies and tactics to sustain the profitability of services and brands that are involved in the sector (Erkmen and Hancer, 2019; Liu et al., 2020; Zhang et al., 
2021). The achieved results take a significant step in proposing several theoretical contributions into brand attachment, brand characteristics, congruence, brand attitude, revisit intentions and WOM in the restaurant sector.

In fact, the present conceptual framework extends insights from previous research studies on the same field (Jalilvand et al., 2016; Rajput and Gahfoor, 2020). Findings expand the literature about factors that can affect WOM and revisit intentions, confirming that brand attitude positively influence revisit intentions and WOM. However, the current research also shows that analysed concepts were positively correlated and that they played an important role in impacting revisit intentions and WOM, apart from one factor: social self-congruity, which was not significantly related to brand attitude.

The present study contributes to this stream of research, highlighting that the degree to which clients assimilate the brand of the restaurant into their self-concepts can develop consumer brand loyalty and cause different levels of intensity within the customer-brand relationship (Han et al., 2015).

Besides, the paper adds some considerations about the need for restaurants to create and maintain a brand (Kim and Ok, 2009; Kim and Stepchenkova, 2018). However, in this sector, small organisations often find it complicated, mainly when bigger competitors have already set the basis for building a renowned brand. Leveraging WOM can aid these firms to develop positive feelings about their services in the mind of their clients, boosting the brand of the restaurant and increasing the clients' intention to revisit (Kwon and Mattila, 2015).

Furthermore, the research adds some insights into the role played by brand image for restaurants (Jin et al., 2012; Erkmen and Hancer, 2019). The brand image is an essential strategic tool as it can help brands, in this field, in reaching their target, in sustaining brand awareness and reputation among clients and in increasing brand loyalty, which, in turn, can result in attaining positive WOM for the brand and in raising the revisit intention.

This study shows that brand quality perceived by clients of restaurants can lead to satisfaction, anticipation and brand image. In fact, findings highlighted that higher brand loyalty and a strong restaurant image can enhance the expectations of clients, "push" them to return to the same location and create positive WOM. Thus, managers of restaurants have to consider both satisfaction and image as factors able to affect revisit intentions, as they can help them attain a wider revisit intention in their clients.

Additionally, the skills of human resources have to be considered as essential for strengthening the perception of brand quality. Hence, huge attention needs to be paid to the selection and training path of human resources behaviour as they are in charge of taking care of clients in the restaurants. In fact, boosting the employees' capabilities in this area involves providing more professional services that can result in enhancing the quality of the service itself and in rising clients' satisfaction and revisit intentions.

Besides, it is essential to try to set the basis for a good reputation in order to reinforce the positive image of the restaurant too. This aim can be reached, thanks to different strategies and tactics. For example, feedback expressed by clients can be published on the restaurant website. Additionally, creating an efficient network that involves not only customers but also partners can be another way to boost brand image and push clients to recommend to others the restaurant and its brand.

Moreover, it is clear that strengthening the value offered to clients can help the company to attain a better positioning and raise the demand. The first stage entails identifying the level of perceived value, taking into account the client perspective. Understanding what value means to clients aids to offer successful performance and build a good brand image. Hence, practitioners who continuously ask for their clients' feedback are following the right path, as they are able to have a better idea of what matters to consumers and what are their real expectations. 
BFJ 123,13

Finally, marketers should try their best in order to avoid that judgments and sanctions could threaten clients who decide to express their comments and opinions leveraging on WOM tactics. Thus, WOM needs to be seen as a convenient way to talk "to" and "about" the restaurant.

\section{Conclusions, limitations and future research}

The purpose of this research is to explore how brand attachment, brand characteristics and congruence impact brand attitude while boosting WOM and revisit intentions in the restaurant sector. The paper concluded that a brand attitude is significantly and positively related to all variables, except for social self-congruity. Besides, in practice, this study shows restaurant managers how to assess the strength of the selected items not only individually but also considering the main impacts and effects that link them all.

In attaining its goal, the research shows several limitations and; thus, it offers some insights for future research. The explored existing relationships among constructs were analysed at a single point in time, and this involves that there is a need to develop longitudinal studies that can boost the research approach and can deeper explore the impacts of the chosen issues in different time periods.

Moreover, the paper focused on Pakistan clients of restaurants, and further studies can explore different geographic areas and compare the collected data with our results in order to better understand consumers' attitudes towards brands internationally and to attain a greater level of generalisation. Additionally, the culture, considered as a variable, in different nations may affect differently the items selected in the proposed conceptual model. This can be analysed by further studies to use cross-cultural data for strengthening generalisability.

Considering the relevance of the subject and the time limitations, data were collected by utilizing a convenience sample. Thus, further studies have to evaluate the framework by employing other techniques and methods, such as, for example, in-depth interviews and focus groups in which the data could be triangulated.

Finally, more insights into the selected topics can be attained by collecting data from developed countries in which clients may have a different approach to restaurant brands. These circumstances might offer a better comprehension of the conceptual model by comparing data collected in developed geographic areas with others attained in developing and under-developed countries.

\section{References}

Aaker, D.A. (1996), "Measuring brand equity across products and markets", California Management Review, Vol. 38 No. 3, pp. 102-120.

Ahn, J. and Back, K.-J. (2018), "Beyond gambling: mediating roles of brand experience and attitude", International Journal of Contemporary Hospitality Management, Vol. 30 No. 10, pp. 3026-3039.

Ajzen, I. (1985), "From intentions to actions: a theory of planned behavior", in Action control, Springer, Berlin, Heidelberg, pp. 11-39.

Ajzen, I. (2002), "Perceived behavioral control, self-efficacy, locus of control, and the theory of planned behavior", Journal of Applied Social Psychology, Vol. 32 No. 4, pp. 665-683.

Ansary, A. and Hashim, N.M.H.N. (2018), "Brand image and equity: the mediating role of brand equity drivers and moderating effects of product type and word-of-mouth", Review of Managerial Science, Vol. 12 No. 4, pp. 969-1002.

Assiouras, I., Liapati, G., Kouletsis, G. and Koniordos, M. (2015), "The impact of brand authenticity on brand attachment in the food industry", British Food Journal, Vol. 117 No. 2, pp. 538-552.

Aureliano-Silva, L., Alves, C.A. and Moretti, S.L.D.A. (2019), "The role of informational and congruence clues in advertisement for an ethnic restaurant", Journal of Food Products Marketing, Vol. 25 No. 3, pp. 322-339. 
Bahri-Ammari, N., Niekerk, M.V., Ben Khelil, H. and Chtioui, J. (2016), "The effects of brand attachment on behavioral loyalty in the luxury restaurant sector", International Journal of Contemporary Hospitality Management, Vol. 28 No. 3, pp. 559-585.

Bauman, M.J. and Taylor, C.D. (2019), “An exploratory study on Texas wine club members' intention to remain", International Journal of Wine Business Research, Vol. 32 No. 1, pp. 41-58.

Bhatta, R.P. (2016), "Social media and brand attitude: an empirical study on social media campaigns of corporate brands in Nepal", Advances in Economics and Business Management, Vol. 3 No. 6 , pp. 591-596.

Bowden, J. (2009), "Customer engagement: a framework for assessing customer-brand relationships: the case of the restaurant industry", Journal of Hospitality Marketing and Management, Vol. 18 No. 6, pp. 574-596.

Brexendorf, T.O., Mühlmeier, S., Tomczak, T. and Eisend, M. (2010), "The impact of sales encounters on brand loyalty", Journal of Business Research, Vol. 63 No. 11, pp. 1148-1155.

Butcher, L., Phau, I. and Teah, M. (2016), "Brand prominence in luxury consumption: will emotional value adjudicate our longing for status?”, Journal of Brand Management, Vol. 23 No. 6, pp. 701-715.

Camp, L. (1996), "Latest thinking on the optimisation of brand use in financial services marketing", Journal of Brand Management, Vol. 3 No. 4, pp. 241-247.

Casidy, R. and Wymer, W. (2015), "The impact of brand strength on satisfaction, loyalty and wom: an empirical examination in the higher education sector", Journal of Brand Management, Vol. 22 No. 2, pp. 117-135.

Chatzopoulou, E. and Tsogas, M. (2017), "The role of emotions to brand attachment and brand attitude in a retail environment", Creating Marketing Magic and Innovative Future Marketing Trends, Springer, Cham, pp. 43-47.

Chen, Y.-S., Hung, S.-T., Wang, T.-Y., Huang, A.-F. and Liao, Y.-W. (2017), "The influence of excessive product packaging on green brand attachment: the mediation roles of green brand attitude and green brand image", Sustainability, Vol. 9 No. 4, p. 654.

Dall'Olmo Riley, F. and De Chernatony, L. (2000), “The service brand as relationships builder”, British Journal of Management, Vol. 11 No. 2, pp. 137-150.

Daniels, K., Glover, J. and Mellor, N. (2014), “An experience sampling study of expressing affect, daily affective well-being, relationship quality, and perceived performance”, Journal of Occupational and Organizational Psychology, Vol. 87 No. 4, pp. 781-805.

De Vaus, D. (2002), Analyzing Social Science Data, Sage Publications, London.

Erkmen, E. and Hancer, M. (2019), "Building brand relationship for restaurants: an examination of other customers, brand image, trust, and restaurant attributes", International Journal of Contemporary Hospitality Management, Vol. 31 No. 3, pp. 1469-1487.

Faircloth, J.B., Capella, L.M. and Alford, B.L. (2001), "The effect of brand attitude and brand image on brand equity", Journal of Marketing Theory and Practice, Vol. 9 No. 3, pp. 61-75.

Ferraro, R., Kirmani, A. and Matherly, T. (2013), "Look at me! Look at me! Conspicuous brand usage, self-brand connection, and dilution", Journal of Marketing Research, Vol. 50 No. 4, pp. 477-488.

Fornell, C. and Larcker, D.F. (1981), "Structural equation models with unobservable variables and measurement error: algebra and statistics", Journal of Marketing Research, Vol. 18 No. 3, pp. 382-388.

Fouladivanda, F., Pashandi, M.A., Hooman, A. and Khanmohammadi, Z. (2013), "The effect of brand equity on consumer buying behavior in term of FMCG in Iran", Interdisciplinary Journal of Contemporary Research in Business, Vol. 4 No. 9, pp. 945-957.

$\mathrm{Fu}, \mathrm{X}$., Kang, J. and Tasci, A. (2017), "Self-congruity and flow as antecedents of attitude and loyalty towards a theme park brand", Journal of Travel \& Tourism Marketing, Vol. 34 No. 9, pp. 1261-1273. 
$\mathrm{BFJ}$ 123,13

Geisser, S. (1975), "The predictive sample reuse method with applications", Journal of the American Statistical Association, Vol. 70 No. 350, pp. 320-328.

George, J.F. (2004), "The theory of planned behavior and internet purchasing", Internet Research, Vol. 14 No. 3, pp. 198-212.

Ghorban, Z.S. (2012), "Brand attitude, its antecedents and consequences. Investigation into smartphone brands in Malaysia”, Journal of Business and Management, Vol. 2 No. 3, pp. 31-35.

Gómez-Suárez, M., Paiva, G. and Schnettler, B. (2016), "Private labels in Chile: influential factors in the purchase intention", Handbook of Research on Strategic Retailing of Private Label Products in a Recovering Economy, IGI Global, pp. 79-102.

Godin, G. and Kok, G. (1996), "The theory of planned behavior: a review of its applications to healthrelated behaviors", American Journal of Health Promotion, Vol. 11 No. 2, pp. 87-98.

Gonzalez-Jimenez, H., Fastoso, F. and Fukukawa, K. (2019), "How independence and interdependence moderate the self-congruity effect on brand attitude: a study of east and west", Journal of Business Research, Vol. 103, pp. 293-300.

Grace, D. and O'Cass, A. (2005), "Service branding: consumer verdicts on service brands", Journal of Retailing and Consumer Services, Vol. 12 No. 2, pp. 125-139.

Gupta, P.B. and Lord, K.R. (1998), "Product placement in movies: the effect of prominence and mode on audience recall", Journal of Current Issues and Research in Advertising, Vol. 20 No. 1, pp. 47-59.

Hair, J.F., Sarstedt, M., Hopkins, L. and Kuppelwieser, V.G. (2014), "Partial least squares structural equation modeling (pls-sem) an emerging tool in business research", European Business Review, Vol. 26 No. 2, pp. 106-121.

Hair, J.F., Hult, G.T.M., Ringle, C. and Sarstedt, M. (2016), A Primer on Partial Least Squares Structural Equation Modeling (PLS-SEM), Sage Publications, London.

Han, H., Back, K.J. and Barrett, B. (2009), "Influencing factors on restaurant customers' revisit intention: the roles of emotions and switching barriers", International Journal of Hospitality Management, Vol. 28 No. 4, pp. 563-572.

Han, S.H., Nguyen, B. and Lee, T.J. (2015), "Consumer-based chain restaurant brand equity, brand reputation, and brand trust", International Journal of Hospitality Management, Vol. 50, pp. 84-93.

Han, S.H., Nguyen, B. and Simkin, L. (2016), "The dynamic models of consumers' symbolic needs: in the context of restaurant brands", European Journal of Marketing, Vol. 50 No. 7, pp. 1348-1376.

Han, H., Yu, J., Chua, B.-L., Lee, S. and Kim, W. (2019), "Impact of core-product and service-encounter quality, attitude, image, trust and love on repurchase: full-service vs low-cost carriers in South Korea”, International Journal of Contemporary Hospitality Management, Vol. 31 No. 4, pp. 1588-1608.

Hanaysha, J. (2016), "Examining the link between word of mouth and brand equity: a study on international fast food restaurants in Malaysia”, Journal of Asian Business Strategy, Vol. 6 No. 3, p. 41.

Heath, Y. and Gifford, R. (2002), "Extending the theory of planned behavior: predicting the use of public transportation 1", Journal of Applied Social Psychology, Vol. 32 No. 10, pp. 2154-2189.

Herold, K., Tarkiainen, A. and Sundqvist, S. (2016), "How the source of word-of-mouth influences information processing in the formation of brand attitudes", Journal of Marketing for Higher Education, Vol. 26 No. 1, pp. 64-85.

Hussein, A.S. (2018), "Effects of brand experience on brand loyalty in Indonesian casual dining restaurant: roles of customer satisfaction and brand of origin", Tourism and Hospitality Management, Vol. 24 No. 1, pp. 119-132.

Hwang, J. and Ok, C. (2013), "The antecedents and consequence of consumer attitudes toward restaurant brands: a comparative study between casual and fine dining restaurants", International Journal of Hospitality Management, Vol. 32, pp. 121-131. 
Jalilvand, M.R., Pool, J.K., Nasrolahi Vosta, S. and Kazemi, R.V. (2016), “Antecedents and consequence of consumers' attitude towards brand preference: evidence from the restaurant industry", Anatolia, Vol. 27 No. 2, pp. 167-176.

Jin, N., Lee, S. and Huffman, L. (2012), "Impact of restaurant experience on brand image and customer loyalty: moderating role of dining motivation", Journal of Travel and Tourism Marketing, Vol. 29 No. 6, pp. 532-551.

Kang, J., Tang, L., Lee, J.Y. and Bosselman, R.H. (2012), "Understanding customer behavior in namebrand Korean coffee shops: the role of self-congruity and functional congruity", International Journal of Hospitality Management, Vol. 31 No. 3, pp. 809-818.

Keller, J.M. (2008), "First principles of motivation to learn and e3-learning”, Distance Education, Vol. 29 No. 2, pp. 175-185.

Khan, N.R. and Shaikh, U. (2011), "Impact of service quality on customer satisfaction: evidences from the restaurant industry in Pakistan", Management and Marketing, Vol. 9 No. 2, pp. 343-355.

Kim, J.H. (2015), "Self-congruity effects: a critical review and an integrative model", Japanese Psychological Research, Vol. 57 No. 4, pp. 348-362.

Kim, J. and Joung, H.-M. (2016), "Psychological underpinnings of luxury brand goods repurchase intentions: brand-self congruity, emotional attachment, and perceived level of investment made", Journal of Global Scholars of Marketing Science, Vol. 26 No. 3, pp. 284-299.

Kim, W. and Ok, C. (2009), "The effects of relational benefits on customers' perception of favorable inequity, affective commitment, and repurchase intention in full-service restaurants", Journal of Hospitality and Tourism Research, Vol. 33 No. 2, pp. 227-244.

Kim, M.S. and Stepchenkova, S. (2018), "Examining the impact of experiential value on emotions, selfconnective attachment, and brand loyalty in Korean family restaurants", Journal of Quality Assurance in Hospitality and Tourism, Vol. 19 No. 3, pp. 298-321.

Kumagai, K. and Nagasawa, S. (2016), “The influence of social self-congruity on Japanese consumers' luxury and non-luxury apparel brand attitudes", Luxury Research Journal, Vol. 1 No. 2, pp. 128-149.

Kumagai, K. and Nagasawa, S. (2019), "Psychological switching mechanism of consumers' luxury and non-luxury brand attitude formation: the effect of store location prestige and self-congruity", Heliyon, Vol. 5 No. 5, p. 01581.

Kumar, V. (2016), "Examining the role of destination personality and self-congruity in predicting tourist behavior", Tourism Management Perspectives, Vol. 20, pp. 217-227.

Kwon, E. and Mattila, A.S. (2015), "The effect of self-brand connection and self-construal on brand lovers' word-of-mouth", Cornell Hospitality Quarterly, Vol. 56 No. 4, pp. 427-435.

Langaro, D., Rita, P. and de Fátima Salgueiro, M. (2018), "Do social networking sites contribute for building brands? Evaluating the impact of users' participation on brand awareness and brand attitude", Journal of Marketing Communications, Vol. 24 No. 2, pp. 146-168.

Lee, Y.K., Back, K.J. and Kim, J.Y. (2009), "Family restaurant brand personality and its impact on customer's emotion, satisfaction, and brand loyalty", Journal of Hospitality and Tourism Research, Vol. 33 No. 3, pp. 305-328.

Lee, H.-M., Chen, T., Hsu, Y.-H. and Wu, Y.-C. (2018), "Effect of complementary product fit and brand awareness on brand attitude after m\&as: word-of-mouth as a moderator", Global Journal of Business Research, Vol. 12 No. 1, pp. 51-67.

Liu, C.-H.S. and Lee, T. (2016), "Service quality and price perception of service: influence on word-ofmouth and revisit intention", Journal of Air Transport Management, Vol. 52, pp. 42-54.

Liu, F., Li, J., Mizerski, D. and Soh, H. (2012), "Self-congruity, brand attitude, and brand loyalty: a study on luxury brands", European Journal of Marketing, Vol. 46 Nos 7/8, pp. 922-937.

Liu, M.T., Wong, I.A., Tseng, T.-H., Chang, A.W.-Y. and Phau, I. (2017), “Applying consumer-based brand equity in luxury hotel branding", Journal of Business Research, Vol. 81, pp. 192-202. 
BFJ 123,13

Liu, K.N., Hu, C., Lin, M.C., Tsai, T.I. and Xiao, Q. (2020), "Brand knowledge and non-financial brand performance in the green restaurants: mediating effect of brand attitude", International Journal of Hospitality Management, Vol. 89, p. 102566.

Lu, A.C., Gursoy, D. and Lu, C.Y. (2015), "Authenticity perceptions, brand equity and brand choice intention: the case of ethnic restaurants", International Journal of Hospitality Management, Vol. 50, pp. 36-45.

Malik, S., Jaswal, L.H., Malik, S.A. and Awan, T.M. (2013), "Measuring service quality perceptions of the customers of restaurant in Pakistan", International Journal for Quality Research, Vol. 7 No. 2, pp. 187-200.

Martin, W.C. (2017), "Positive versus negative word-of-mouth: effects on receivers", Academy of Marketing Studies Journal, Vol. 21 No. 2, pp. 1-10.

Mizik, N. (2014), "Assessing the total financial performance impact of brand equity with limited timeseries data", Journal of Marketing Research, Vol. 51 No. 6, pp. 691-706.

Moore, D.J. and Homer, P.M. (2008), "Self-brand connections: the role of attitude strength and autobiographical memory primes", Journal of Business Research, Vol. 61 No. 7, pp. 707-714.

Nam, J., Ekinci, Y. and Whyatt, G. (2011), "Brand equity, brand loyalty and consumer satisfaction”, Annals of Tourism Research, Vol. 38 No. 3, pp. 1009-1030.

Namin, A. (2017), "Revisiting customers' perception of service quality in fast food restaurants", Journal of Retailing and Consumer Services, Vol. 34, pp. 70-81.

Nunally, J.C. and Bernstein, I.H. (1994), Psychometric Theory, McGraw-Hill, New York, NY, Vol. 3.

Ogunnaike, O.O., Kehinde, O.J., Omoyayi, O.O., Popoola, O.O. and Amoruwa, A. (2017), "Conceptualization of the relationship between brand equity and purchase behavior", International Review of Management and Marketing, Vol. 7 No. 2, pp. 403-408.

O'Cass, A. and Weerawardena, J. (2010), "The effects of perceived industry competitive intensity and marketing-related capabilities: drivers of superior brand performance", Industrial Marketing Management, Vol. 39 No. 4, pp. 571-581.

Pace, S., Balboni, B. and Gistri, G. (2017), "The effects of social media on brand attitude and wom during a brand crisis: evidences from the barilla case", Journal of Marketing Communications, Vol. 23 No. 2, pp. 135-148.

Parasuraman, A. (1987), "Customer-oriented corporate cultures are crucial to services marketing success", Journal of Services Marketing, Vol. 1 No. 1, pp. 39-46.

Park, H.-J. and Lee, T.J. (2019), "Influence of the 'slow city' brand association on the behavioural intention of potential tourists", Current Issues in Tourism, Vol. 22 No. 12, pp. 1405-1422.

Podnar, K. and Javernik, P. (2012), "The effect of word-of-mouth on consumers' attitudes toward products and their purchase probability", Journal of Promotion Management, Vol. 18 No. 2, pp. 145-168.

Pradhan, D., Duraipandian, I. and Sethi, D. (2016), "Celebrity endorsement: how celebrity-brand-user personality congruence affects brand attitude and purchase intention", Journal of Marketing Communications, Vol. 22 No. 5, pp. 456-473.

Rafiee, V.B., Shen, K.N. and Arab, U. (2016), “The impact of corporate response strategies to negative online word of mouth on complainers' brand attitude", Paper Presented at the PACIS.

Rajput, A. and Gahfoor, R.Z. (2020), "Satisfaction and revisit intentions at fast food restaurants", Future Business Journal, Vol. 6, pp. 1-12.

Razak, N., Themba, O.S. and Sjahruddin, H. (2019), "Brand awareness as predictors of repurchase intention: brand attitude as a moderator", Advances in Social Sciences Research Journal, Vol. 6 No. 2, pp. 1-20.

Rezza, A.M. (2018), "The role of consumer's self-congruence in the formation of brand attitude", Jurnal Sekretaris and Administrasi Bisnis (JSAB), Vol. 2 No. 1, pp. 11-18. 
Robinson, C., Abbott, J. and Shoemaker, S. (2005), "Recreating cheers: an analysis of relationship marketing as an effective marketing technique for quick-service restaurants", International Journal of Contemporary Hospitality Management, Vol. 17 No. 7, pp. 590-599.

Sabir, R.I., Irfan, M., Akhtar, N., Pervez, M.A. and ur Rehman, A. (2014), "Customer satisfaction in the restaurant industry; examining the model in local industry perspective", Journal of Asian Business Strategy, Vol. 4 No. 1, p. 18.

Saeed, R., Javed, S. and Nawaz, R. (2013), "Empirical Study of factors affecting brand loyalty: evidence from fast food restaurants in Pakistan", Journal of Basic and Applied Scientific Research, Vol. 3 No. 12 , pp. 46-55.

Sarker, M.M., Mohd-Any, A.A. and Kamarulzaman, Y. (2019), "Conceptualising consumer-based service brand equity (CBSBE) and direct service experience in the airline sector", Journal of Hospitality and Tourism Management, Vol. 38, pp. 39-48.

Saunders, J. and Watters, R. (1993), "Branding financial services", International Journal of Bank Marketing, Vol. 11 No. 6, pp. 32-38.

Sean Hyun, S. and Kim, W. (2011), "Dimensions of brand equity in the chain restaurant industry", Cornell Hospitality Quarterly, Vol. 52 No. 4, pp. 429-437.

Seo, J.H., Kim, J.-O. and Choi, W.-S. (2015), "Effects of physical environment on brand loyalty and moderated effects of brand image", International Journal of Research, Vol. 50, pp. 1-15.

Sikandar, M.D.I. and Ahmed, Q.M. (2019), "Impact of social media marketing on brand love: promoting loyalty in the restaurant landscape of Pakistan", Online Journal of Communication and Media Technologies, Vol. 9 No. 4, p. 201927.

Singh, R.P. and Banerjee, N. (2018), "Exploring the influence of celebrity credibility on brand attitude, advertisement attitude and purchase intention", Global Business Review, Vol. 19 No. 6, pp. 1622-1639.

Sinthamrong, P. and Rompho, N. (2015), "Factors affecting attitudes and purchase intentions toward branded content on webisodes", Journal of Management Policy and Practice, Vol. 16 No. 4, p. 64 .

Sirgy, M.J. (2018), "Self-congruity theory in consumer behavior: a little history", Journal of Global Scholars of Marketing Science, Vol. 28 No. 2, pp. 197-207.

VanMeter, R., Syrdal, H.A., Powell-Mantel, S., Grisaffe, D.B. and Nesson, E.T. (2018), “Don’t just 'like' me, promote me: how attachment and attitude influence brand related behaviors on social media”, Journal of Interactive Marketing, Vol. 43, pp. 83-97.

Wassler, P., Wang, L. and Hung, K. (2019), "Identity and destination branding among residents: how does brand self-congruity influence brand attitude and ambassadorial behavior?", International Journal of Tourism Research, Vol. 21 No. 4, pp. 437-446.

Wetzer, I.M., Zeelenberg, M. and Pieters, R. (2007), “Never eat in that restaurant, I did!: exploring why people engage in negative word-of-mouth communication", Psychology and Marketing, Vol. 24 No. 8, pp. 661-680.

Wu, S.-I. and Wang, W.-H. (2014), "Impact of CSR perception on brand image, brand attitude and buying willingness: a study of a global café", International Journal of Marketing Studies, Vol. 6 No. 6, p. 43.

Zha, D., Melewar, T.C., Foroudi, P. and Jin, Z. (2020), “An assessment of brand experience knowledge literature: using bibliometric data to identify future research direction”, International Journal of Management Reviews, Vol. 22 No. 3, pp. 287-317.

Zhang, Z., Zhang, Z. and Law, R. (2014), "Positive and negative word of mouth about restaurants: exploring the asymmetric impact of the performance of attributes", Asia Pacific Journal of Tourism Research, Vol. 19 No. 2, pp. 162-180.

Zhang, H., Wu, Y. and Buhalis, D. (2018), "A model of perceived image, memorable tourism experiences and revisit intention", Journal of Destination Marketing and Management, Vol. 8, pp. 326-336. 
$\mathrm{BFJ}$

123,13

Zhang, S.N., Li, Y.Q., Liu, C.H. and Ruan, W.Q. (2021), "Reconstruction of the relationship between traditional and emerging restaurant brand and customer WOM", International Journal of Hospitality Management, Vol. 94, p. 102879.

Zhao, X., Lynch, J.G. Jr and Chen, Q. (2010), "Reconsidering baron and kenny: myths and truths about mediation analysis", Journal of Consumer Research, Vol. 37 No. 2, pp. 197-206.

\section{$240 \quad$ Further reading}

Hair, J.F., Hollingsworth, C.L., Randolph, A.B. and Chong, A.Y.L. (2017a), “An updated and expanded assessment of pls-sem in information systems research", Industrial Management and Data Systems, Vol. 117 No. 3, pp. 442-458.

Hair, J.F., Matthews, L.M., Matthews, R.L. and Sarstedt, M. (2017b), "Pls-sem or cb-sem: updated guidelines on which method to use", International Journal of Multivariate Data Analysis, Vol. 1 No. 2, pp. 107-123.

\section{Appendix}

The Appendix files are available online for this article.

\section{Corresponding author}

Maria Palazzo can be contacted at: mpalazzo@unisa.it

For instructions on how to order reprints of this article, please visit our website:

www.emeraldgrouppublishing.com/licensing/reprints.htm

Or contact us for further details: permissions@emeraldinsight.com 